\title{
Penggunaan Modul Berbasis Konstruktivis pada Mata Kuliah Fisika Kuantum untuk Meningkatkan Penguasaan Konsep ditinjau dari Kemampuan Matematik Mahasiswa
}

\author{
Nurhayatia ${ }^{\text {a) }}$ Boisandi ${ }^{\text {b) }}$ \\ IKIP PGRI Pontianak, Jalan Ampera No.88, Pontianak \\ Email: ${ }^{a}$ nurhayatideli@gmail.com, b)bsandi2012@gmail.com
}

\begin{abstract}
To be a good teacher, physical education students should be actively involved in the learning process, but until now the students have not been involved actively. This research was aimed to know the effect modules of constructivist based for mathematical ability and concept student in quantum physics. This study used an experimental method. The population is all students of physical education IKIP-PGRI Pontianak sixth semester of the academic year 2014-2015, consist of three class. Samples were taken at random cluster sampling technique number two classes. Experimental class with constructivist module and the other class with conventional module. Data mastery of concepts and mathematical abilities were measured using a test technique. Hypothesis testing using Kruskal Wallis test contained in SPSS. Based on the results of data analysis can be concluded that: (1) there is the effect of the use of module based constructivist against mastery of concept of the student where the average mastery of concepts students acquire learning using module-based inquiry was higher than students who acquire learning by using conventional module, (2) there is the effect of high and low mathematical ability to mastery of concepts students and (3) there is interaction between the use of constructivist-based module with a mathematical ability to mastery of concepts students.
\end{abstract}

Keywords: Module, constructivist, mastery of concepts, mathematical ability

\begin{abstract}
Abstrak
Untuk menjadi guru yang baik, mahasiswa pendidikan fisika harus terlibat aktif dalam proses pembelajaran, namun sampai sekarang mahasiswa belum terlibat secara aktif. Penelitian ini bertujuan mengetahui pengaruh penggunaan modul berbasis konstruktivis, kemampuan matematik mahasiswa dan interaksinya terhadap penguasaan konsep mahasiswa pada mata kuliah fisika kuantum. Penelitian ini menggunakan metode eksperimen. Populasi adalah seluruh mahasiswa pendidikan fisika semester enam IKIP PGRI Pontianak tahun akademik 2014-2015, sejumlah tiga kelas. Sampel diambil dengan teknik cluster random sampling sejumlah dua kelas. Satu kelas eksperimen 1 dengan modul konstruktivis dan satu kelas eksperimen 2 dengan modul konvensional. Data penguasaan konsep dan kemampuan matematik diukur menggunakan teknik tes. Uji hipotesis menggunakan uji Kruskal Wallis yang terdapat pada program SPSS. Berdasarkan hasil analisis data dapat disimpulkan bahwa: (1) terdapat pengaruh penggunaan modul berbasis konstruktivis terhadap pengusaan konsep mahasiswa dimana rata-rata penguasaan konsep mahasiswa yang memperoleh pembelajaran menggunakan modul berbasis inkuiri lebih tinggi dibandingkan mahasiswa yang memperoleh pembelajaran dengan menggunakan modul konvensional, (2) terdapat pengaruh kemampuan
\end{abstract}


matematik tinggi dan rendah terhadap penguasaan konsep mahasiswa dan (3) terdapat interaksi antara penggunaan modul berbasis konstruktivis dengan kemampuan matematik terhadap penguasaan konsep mahasiswa.

Kata-kata kunci: Modul, konstruktivis, penguasaan konsep, kemampuan matematik

\section{PENDAHULUAN}

Institut Keguruan dan Ilmu Pendidikan Persatuan Guru Republik Indonesia (IKIP-PGRI) Pontianak merupakan salah satu LPTK di Kalimantan Barat yang bertugas menghasilkan calon guru (tenaga kependidikan) pada berbagai disiplin ilmu yang profesional dan berkualitas yaitu ahli dalam bidang ilmunya dan memiliki daya saing di dunia kerja. Tenaga kependidikan yang dihasilkan diharapkan mampu menerapkan, mengkaji, menelaah dan memecahkan masalah yang dihadapinya baik dalam kehidupan bermasyarakat maupun di dunia kerja nantinya serta siap berkompetisi pada era global. Salah satu tenaga kependidikan yang dipersiapkan oleh IKIP PGRI Pontianak adalah tenaga kependidikan pada bidang fisika. Calon guru fisika yang dihasilkan yaitu calon guru yang berkualitas dan menguasai kompetensi yang baik di bidang kependidikan fisika sehingga siap terjun ke dunia kerja menjadi tenaga kependidikan yang berkualitas.

Berdasarkan kurikulum di program studi pendidikan fisika, salah satu mata kuliah yang wajib ditempuh oleh mahasiswa pendidikan fisika adalah mata kuliah fisika kuantum. Materi pada mata kuliah fisika kuantum bersifat abstrak dan mikroskopis yang mengkaji fenomena fisika di tingkat atomik. Tujuan yang ingin dicapai dalam mata kuliah fisika kuantum bagi mahasiswa pendidikan fisika adalah memiliki kemampuan menerapkan konsep-konsep dasar fisika kuantum pada persoalanpersoalan fisika mikro sederhana serta dapat mengaplikasikannya sesuai dengan perkembangan sains dan teknologi. Namun masih banyak mahasiswa mengalami kesulitan dalam memahami materi kuantum. Terbukti, dalam dua tahun akademik berturutan, rata-rata hasil belajar mahasiswa pada mata kuliah ini berkisar antara 2,30 sampai dengan 2,36 pada skala lima.

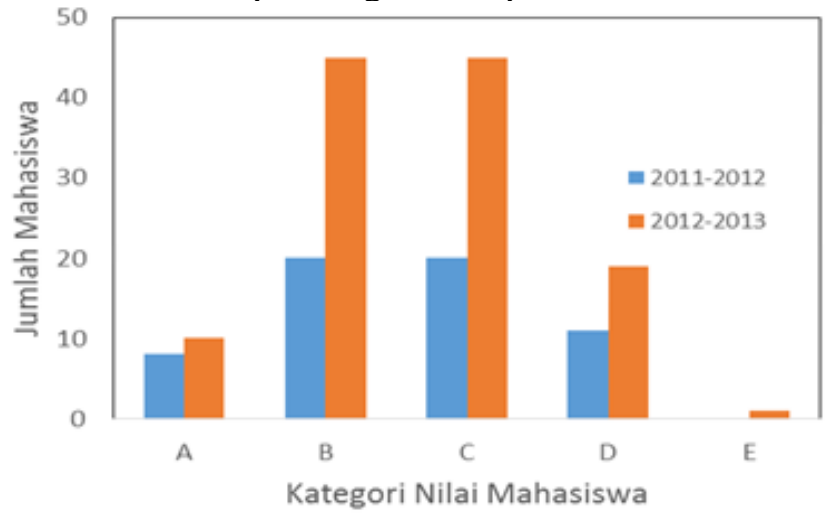

GAMBAR 1. Distribusi Nilai Mahasiswa Berdasarkan Tahun Akademik

Berdasarkan GAMBAR 1, dapat diketahui bahwa terdapat lebih dari 50\% mahasiswa dalam tiap tahun akademiknya tidak berhasil lulus dengan nilai minimal berkategori B. Rendahnya hasil belajar mahasiswa tersebut merupakan indikator rendahnya penguasaan mereka terhadap konsep-konsep mata kuliah fisika kuantum. Jika dibiarkan, hal ini dikhawatirkan akan sangat mempengaruhi kualitas penguasaan mahasiswa dalam materi mata kuliah fisika lanjut, yang memprasyaratkan penguasaan konsep mata kuliah fisika kuantum yang dikenal sebagai ilmu dasar bagi penelaahan gejala dan sifat berbagai sistem mikroskopik (Krane, 1992; Tjia, 1999).

Berdasarkan hasil wawancara dengan beberapa mahasiswa program studi pendidikan fisika yang pernah mengikuti mata kuliah fisika kuantum menunjukkan bahwa hampir $70 \%$ mahasiswa kurang menyenangi dan takut untuk mengikuti mata kuliah ini. Mereka menganggap bahwa materi fisika kuantum bersifat abstrak dan memerlukan kemampuan matematik yang tinggi. Mereka mengatakan bahwa mereka dapat mengerti dan memahami materi perkuliahan yang disajikan dosen, tetapi setelah dihadapkan pada permasalahan yang berkenaan dengan materi fisika kuantum, mereka tidak mampu memecahkan masalah yang dihadapi tersebut. Hal ini menunjukkan bahwa hasil belajar mahasiswa 
pada mata kuliah ini tidak bersifat tahan lama dan berkelanjutan. Akibatnya, mahasiswa tidak mampu menerapkan konsep-konsep yang diperolehnya dalam situasi baru, sehingga pemahaman konsepkonsep materi pada mata kuliah fisika lanjut menjadi kurang yang berimplikasi pula pada rendahnya hasil belajar yang dicapai mahasiswa.

Kesulitan belajar mahasiswa dalam memahami materi fisika kuantum diduga disebabkan oleh beberapa faktor. Pertama, penyajian perkuliahan yang terkesan konvensional sering digunakan sehingga menjadikan mahasiswa kurang aktif dan kreatif dalam belajar. Sistem pembelajaran yang teacher centered ini cenderung untuk menghabiskan materi sesuai dengan target kurikulum, sehingga mahasiswa akan menjadi pasif dan hanya menerima apa yang diberikan oleh dosen. Hal ini akan menyebabkan kurangnya rasa percaya diri mahasiswa terhadap kemampuan mereka yang pada akhirnya akan menurunkan motivasi dalam belajar. Selain itu, menurut Slavin (1994, p. 228), mahasiswa belajar melalui keterlibatan aktif dengan konsep-konsep dan prinsip-prinsip, dan dosen mendorong siswa untuk mendapatkan pengalaman dengan melakukan kegiatan yang memungkinkan mereka menemukan konsep dan prinsip-prinsip untuk diri mereka sendiri. Kedua, sistem evaluasi, dosen hanya terpaku pada penilaian dari hasil Ujian Tengah Semester (UTS), hasil Ujian Akhir Semester (UAS), dan nilai tugas, masing-masing dengan bobot sesuai dengan yang telah disepakati. Ketiga, mahasiswa yang mengikuti perkuliahan fisika kuantum keadaannya sangat heterogen. Mereka berbeda dalam hal bakat, kemampuan awal, kecerdasan, motivasi, kecepatan belajar dan dalam hal lainnya. Sistem perkuliahan dengan metode ekspositori yang masih dominan diterapkan dalam perkuliahan belum mempertimbangkan tingkat perbedaan tersebut. Piaget (dalam Suardana: 2006, p. 4) mengasumsikan bahwa seseorang tumbuh melewati urutan perkembangan yang sama, namun pertumbuhan itu berlangsung pada kecepatan yang berbeda. Oleh karena itu, dosen harus melakukan upaya khusus untuk mengatur kegiatan kelas dalam bentuk individu-individu dan kelompok-kelompok kecil dalam bentuk kelas utuh. Keempat, kurangnya kemandirian mahasiswa dalam belajar. Hal ini dilihat dari kemampuan mahasiswa dalam menyelesaikan soal latihan yang diberikan masih kurang. Padahal soal-soal tersebut merupakan modifikasi dari soal yang telah dicontohkan penyelesaiannya.

Oleh karena itu diperlukan suatu media yang dapat digunakan mahasiswa untuk mengkonstruksi konsep-konsep yang dipelajari. Satu diantaranya adalah modul yang berbasis konstruktivis. Modul merupakan paket belajar mandiri yang meliputi serangkaian pengalaman belajar yang direncanakan serta dirancang secara sistematis untuk membantu siswa mencapai tujuan belajar (Mulyasa 2004, p. 43). Menurut Cipto Utomo dan Kies Ruijter (dalam Suardana 2006, p. 5), "penerapan modul dalam pembelajaran sangat memberikan peluang yang baik bagi pebelajar pada usia dewasa dan dapat mengatasi perbedaan terutama dalam kecepatan belajar bagi mahasiswa. Melalui modul berbasis konstruktivis, pengetahuan mahasiswa tentang materi fisika kuantum dibangun secara bertahap dari hasil yang diperoleh melalui konteks yang terbatas. Pengetahuan yang diperoleh tidak hanya seperangkat fakta, konsep, atau kaidah yang siap diambil dan diingat belaka, melainkan mahasiswa harus mengkonstruksi sendiri pengetahuan tersebut barulah kemudian memberi makna melalui pengetahuan yang nyata.

Berdasarkan latar belakang di atas, maka fokus permasalahan dalam penelitian ini yaitu (1)pengaruh penggunaan modul berbasis konstruktivis terhadap penguasaan konsep mahasiswa, (2)pengaruh kemampuan matematik tinggi dan kemampuan matematik rendah terhadap penguasaan konsep mahasiswa, dan (3)interaksi antara modul berbasis konstruktivis dengan kemampuan matematik terhadap penguasaan konsep mahasiswa.

\section{METODE}

Metode penelitian ini adalah metode eksperimen dengan bentuk eksperimen semu. Rancangan yang dipilih yaitu two way ANOVA. Subjek dalam penelitian ini adalah mahasiswa semester VI Program Studi Pendidikan Fisika IKIP PGRI Pontianak yang sedang mengikuti perkuliahan fisika kuantum sebanyak dua kelas. Jumlah subjek yang dilibatkan dalam penelitian ini adalah 60 orang yang terdiri atas 30 orang kelas eksperimen dan 30 orang kelas kontrol. Hasil uji kesetaraan melalui uji t independent sampel (Budiyono 2009, p. 105) menunjukkan keadaan awal kedua kelas sampel tidak berbeda. 
Teknik yang digunakan untuk mengumpulkan data yaitu teknik tes. Penguasaan konsep diukur melalui tes berbentuk essay dan kemampuan matematik diukur menggunakan tes pilihan ganda. Sebelum instrumen digunakan guna untuk mengambil data, instrumen diujicobakan untuk mengetahui tingkat uji validitas, reliabilitas, daya pembeda, dan tingkat kesukaran (Surapranata 2009 , p. 10). Soal yang digunakan dalam penelitian memiliki kriteria valid dengan reliabilitas yang tinggi.

Teknik analisis data penguasaan konsep diawali dengan uji normalitas dan homogenitas data. Uji normalitas bertujuan untuk mengetahui sampel yang diambil berasal dari populasi yang berdistribusi normal atau tidak normal. Uji ini dilakukan dengan menggunakan program SPSS versi 16 dengan pilihan tes uji yang digunakan yaitu Kolmogorov-Smirnov. Sedangkan uji homogenitas data dilakukan untuk mengetahui suatu sampel berasal dari populasi yang homogen atau tidak homogen. Uji homogenitas menggunakan uji Levene yang juga diolah menggunakan progran SPSS versi 16. Uji prasyarat analisis menunjukkan bahwa sebagian besar data penelitian tidak berdistribusi normal dan homogen, sehingga pengujian hipotesis penelitian ini menggunakan statistik non parametrik yaitu uji Kruskal Wallis. Pengujian hipotesis juga dilakukan dengan bantuan program SPSS (Sulaiman 2005, p. 29).

\section{HASIL DAN PEMBAHASAN}

Penelitian ini bertujuan untuk mengetahui pengaruh penggunaan modul berbasis konstruktivis terhadap penguasaan konsep mahasiswa, pengaruh kemampuan matematik tinggi dan kemampuan matematik rendah terhadap penguasaan konsep mahasiswa, dan interaksi antara modul berbasis konstruktivis dengan kemampuan matematik terhadap penguasaan konsep mahasiswa.

Uji prasyarat analisis meliputi uji normalitas dan uji homogenitas data. Rangkuman uji prasyarat analisis disajikan pada TABEL 1 dan TABEL 2.

TABEL 1. Hasil Uji Normalitas Data Penguasaan Konsep dan Kemampuan Matematik

\begin{tabular}{lllll}
\hline Jenis Data & Kelas & \multicolumn{3}{c}{ Kolmogorov-Smirnov } \\
\cline { 3 - 5 } & & Statistic & df & Sig. \\
\hline Penguasaan Konsep & Eksperimen & 0,230 & 25 & 0,001 \\
& Kontrol & 0,286 & 25 & 0,000 \\
\hline Kemampuan Matematik & Eksperimen & 0,237 & 27 & 0,000 \\
& Kontrol & 0,275 & 23 & 0,000 \\
\hline
\end{tabular}

TABEL 2. Hasil Uji Homogenitas Data Penguasaan Konsep dan Kemampuan Matematik

\begin{tabular}{lllll}
\hline \multirow{2}{*}{ Data } & \multicolumn{4}{c}{ Levene Test } \\
\cline { 2 - 5 } & Statistic & $\mathbf{d f}_{\mathbf{1}}$ & $\mathbf{d f}_{\mathbf{2}}$ & Sig. \\
\hline Penguasaan Konsep & 5,962 & 1 & 49 & 0,018 \\
Kemampuan Matematik & 5,681 & 1 & 48 & 0,021 \\
\hline
\end{tabular}

Berdasarkan TABEL 1 dan TABEL 2, diketahui bahwa nilai signifikansi perhitungan (sig.) perhitungan lebih kecil dibandingkan dengan taraf signifikansi yang digunakan dalam penelitian ini $(0,05)$. Sehingga dapat dikatakan bahwa kelompok data penelitian tidak berasal dari populasi yang berdistribusi normal (TABEL 1) dan bersifat homogen (TABEL 2). Karena data penelitian tidak berdistribusi normal maka pengujian hipotesis peneltian dilakukan dengan statistik non-parametrik.

Hipotesis nil (Ho) dalam penelitian ini antara lain: (a) tidak terdapat pengaruh penggunaan modul berbasis konstruktivis terhadap penguasaan konsep mahasiswa, (b) tidak terdapat pengaruh kemampuan matematik tinggi dan kemampuan matematik rendah terhadap penguasaan konsep mahasiswa, dan (c) tidak terdapat interaksi antara modul berbasis konstruktivis dengan kemampuan matematik terhadap penguasaan konsep mahasiswa. Rangkuman hasil uji hipotesis penelitian menggunakan uji Kruskal Wallis dapat dilihat pada TABEL 3 berikut. 
TABEL 3. Hasil Uji Hipotesis

\begin{tabular}{llll}
\hline \multirow{2}{*}{ Dependent Variable } & \multicolumn{3}{c}{ Kruskal Wallis } \\
\cline { 2 - 4 } & Chi-Square & df & Sig. \\
\hline Penguasaan Konsep & 8,844 & 1 & 0,003 \\
Kemampuan Matematik & 14,057 & 1 & 0,000 \\
Interaksi & 15,768 & 3 & 0,001 \\
\hline
\end{tabular}

Berdasarkan TABEL 3, diketahui bahwa nilai signifikansi lebih besar dari 0,005 sehingga dapat disimpulkan bahwa Ho ditolak dan Ha diterima. Hal ini berarti (a) terdapat pengaruh penggunaan modul berbasis konstruktivis terhadap penguasaan konsep mahasiswa, (b) terdapat pengaruh kemampuan matematik tinggi dan kemampuan matematik rendah terhadap penguasaan konsep mahasiswa, dan (c) terdapat interaksi antara modul berbasis konstruktivis dengan kemampuan matematik terhadap penguasaan konsep mahasiswa.

Penguasaan konsep mahasiswa yang diajar dengan menggunakan modul berbasis konstruktivis jika dilihat dari nilai rata-rata lebih baik dibandingkan mahasiswa yang diajar dengan modul konvensional dikarenakan melalui modul dengan pendekatan konstruktivis, mahasiswa dilatih untuk dapat belajar secara mandiri dengan ada atau tanpa bantuan dosen, mampu menemukan sendiri konsep yang dipelajari, dengan penggunaan simbol yang tepat diharapkan mahasiswa mampu melatih kemampuan berpikir abstrak, mampu menemukan pemecahan masalah yang diberikan di awal modul serta dapat mengaitkan informasi baru dengan konsep-konseop relevan yang terdapat dalam struktur kognitif mahasiswa (Brooks dan Brooks, 1993). Hal ini juga sejalan dengan teori belajar Ausubel yaitu belajar bermakna akan terjadi bila mahasiswa menemukan sendiri pengetahuannya, dan dikatakan juga belajar bermakna jika pada proses pembelajaran mengaitkan informasi baru pada konsep-konsep relevan yang terdapat dalam struktur kognitif mahasiswa. Selain itu, menurut Bruner, proses pembelajaran akan lebih baik jika mahasiswa diberikan kesempatan untuk menemukan dan membuktikan suatu konsep, teori, aturan melalui contoh yang mereka jumpai dalam kehidupan sehari-hari (Trianto 2010, p. 38).

Hasil yang dicapai dalam penelitian ini relevan dengan temuan Sandra (1999) yang menyatakan bahwa penerapan model belajar mandiri secara efektif dapat meningkatkan hasil belajar mahasiswa, dan temuan Suardana (2006) yang menyimpulkan bahwa penerapan modul berwawasan konstruktivis dapat meningkatkan hasil belajar mahasiswa.

Potensial osilator harmonik sederhana merupakan materi kuantum yang memerlukan kemampuan matematika yang tinggi. Pada materi ini mahasiswa diharapkan dapat memperoleh persamaan fungsi gelombang, probabilitas dan energi melalui penjabaran matematis yang rumit. Oleh karena itu, mahasiswa yang mempunyai kemampuan matematik dasar yang tinggi akan lebih mudah memahami materi dibandingkan mahasiswa yang memiliki kemampuan matematik rendah.

\section{PENUTUP}

Berdasarkan penelitian yang telah dilakukan, dapat disimpulkan bahwa (a) terdapat pengaruh penggunaan modul berbasis konstruktivis terhadap penguasaan konsep mahasiswa, (b) terdapat pengaruh kemampuan matematik tinggi dan kemampuan matematik rendah terhadap penguasaan konsep mahasiswa, dan (c) terdapat interaksi antara modul berbasis konstruktivis dengan kemampuan matematik terhadap penguasaan konsep mahasiswa.

\section{UCAPAN TERIMA KASIH}

Penelitian ini dibiayai oleh DIKTI sehingga peneliti mengucapkan terima kasih yang sebesarbesarnya kepada DIKTI atas bantuan yang diberikan. Selain itu peneliti juga mengucapkan terima kasih kepada IKIP PGRI Pontianak yang telah memberikan dukungan sehingga penelitian ini bisa terlaksana. 


\section{REFERENSI}

Budiyono 2009, Statistik untuk Penelitian Edisi Ke-2, Universitas Sebelas maret Press, Surakarta.

Brooks, J.G. \& Brooks, M.G 1993, In Search Of Understanding: The Case For Constructivist Classrooms, Association for Supervision and Curriculum Development (ASCD), Alexandria.

Krane, K 1992, Modern Physics. Singapore, John Wiley \&Sonc, Inc.

Mulyasa, E 2004, Kurikulum Berbasis Kompetensi: Konsep, Karakteristik, dan Implementasi, Bandung: Remaja Rosdakarya.

Sandra, K 1999, Self-Directed Learning, viewed 20 Februari 2015, http://www.utc.edu/Teaching Resource-Center.

Slavin, R.E 2008, Cooperative Learning, Teori, Riset dan Praktik, Penerjemah. Nurulita Yusron, Bandung, Penerbit Nusa Media.

Suardana 2006, 'Pembelajaran Modul Yang Berwawasan Konstruktivis: Upaya Meningkatkan Kemampuan Belajar Mandiri Dan Hasil Belajar Mahasiswa Pada Mata Kuliah Fisika Kuantum', Jurnal Pendidikan dan Pengajaran IKIP Negeri Singaraja No.2 Tahun XXXIX April.

Sulaiman, W 2005, Statistik Non-Parametrik: Contoh kasus dan Pemecahannya dengan SPSS, Andi Publisher, Yogjakarta.

Surapranata, S 200, Analisis, Validitas, Reliabilitas dan Intepretasi Hasil Tes-Implementasi Kurikulum 2004, Remaja Rosdakarya, Bandung.

Trianto 2010, Mendesain Model Pembelajaran Inovatif-Progresif, Kencana Prenata Media Group, Jakarta. 